\title{
The thermal damaging process of diorite under microwave irradiation
}

\author{
He Leping \\ State Key Laboratory of Oil and Gas Reservoir Geology and Exploitation, Southwest Petroleum University, Chengdu 610500, \\ China \\ 171278402@qq.com, bttps://orcid.org/0000-0002-9554-2755
}

Chen Yuan, Zeng Junsen, Hu Qijun

School of Civil Engineering and Architecture, Southwest Petroleum University, Chengdu 610500, China

965742308@qq.com, bttps://orcid.org/0000-0002-7720-2482

8454491134@qq.com, bttps://orcid.org/0000-0002-3194-7702

buqijunswpu@163.com, bttps://orcid.org/0000-0002-9747-4311

\section{Shao Dadong}

School of environmental and biological engineering, Nanjing University of Science and Technology, Nanjing 210094, China shaodadong@126.com, https://orcid.org/0000-0002-9778-0554

\section{Zhang haibin}

Institute of Nuclear Physics and Chemistry, China Academy of Engineering Physics, Mianyang 621900, China

155046169@qq.com, bttp://orcid.org/0000-0003-1297-7946

\section{Lu Xirui}

State Key Laboratory of Environment-Friendly Energy Materials, Southwest University of Science and Technology, Mianyang 621010, China

luxiruimvp116@163.com, bttps:/ / orcid.org/0000-0003-4751-8408

ABSTRACT. Laboratory tests have been conducted to investigate the effects of thermal damage on diorite under microwave irradiation. The sample rocks were heated to high temperature range of 300 to $800{ }^{\circ} \mathrm{C}$ in a single-mode microwave furnace. The experimental results show that the rocks started to crack at $500{ }^{\circ} \mathrm{C}$ and completely disintegrated at $700{ }^{\circ} \mathrm{C}$. The intensities of quartz diffraction peaks were almost unchanged while the diffraction peak intensity of hornblende gradually decreased with temperature increasing. In addition, the chlorite diffraction peak disappeared at $500{ }^{\circ} \mathrm{C}$. The compressive strength of the sample decreased to $40 \%$ at $600{ }^{\circ} \mathrm{C}$ and it approached zero at $700{ }^{\circ} \mathrm{C}$. In this paper, the possible reasons for the thermal effects on the fracture of diorite were discussed, which can be related to water evaporation,

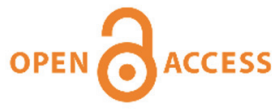

Citation: Leping, H., Yuan, C., Junsen, Z., Qijun, H., Dadong, D., Haibin, Z., Xirui, L., The thermal damaging process of diorite under microwave irradiation, Frattura ed Integrità Strutturale, 47 (2019) 65-73.

Received: 10.10 .2018

Accepted: 08.11 .2018

Published: 01.01.2019

Copyright: (C) 2019 This is an open access article under the terms of the CC-BY 4.0, which permits unrestricted use, distribution, and reproduction in any medium, provided the original author and source are credited. 
thermal cracks and mismatch thermal expansion, and phase transition on quartz. The result indicates that diorite can be effectively destroyed under microwave irradiation.

KEYWORDS. Microwave heating; Thermal damage; Diorite; Rock breakage.

\section{INTRODUCTION}

$\mathrm{I}$ ncreasing the rock fragmentation rate and reducing energy consumption are the trends in the tunnel and mining engineering industries currently. Traditional methods, such as mechanical excavators and explosive approaches, have drawbacks as high energy consumption and serious pollution. Besides, these methods will be challenged on breakage rate and apparatus wear and tear when encountering massive hard rock. Therefore, these industries are seeking a new way to overcome these difficulties. As rocks would crack and even be melt under the microwave irradiation, microwave treatment is considered as a potential rock fragmentation method [1,2].

Minerals can absorb microwaves to generate heat and weaken the mechanical properties by the effect of high temperatures. The microwave absorption capability of minerals depends on whose type [3] and dielectric constant [4]. Compared with the traditional heating methods, the advantages of microwave heating are rapidly volumetric-heating, selective-heating and energy-saving [5]. In the 1980s, Chen et al. found out that microwaves had a certain influence on most natural minerals [6], which plays a guiding role in the study of microwave rock breaking.

In the mining experimental, it had demonstrated that microwave irradiation reduces the energy required for mineral fragmentation [7], affects surface characteristics of ores and changes fracture modes, which was great helpful in sorting ores and increasing the release of minerals [8-10]. In the mining numerical simulation, it was found out that the highest temperatures and temperature gradients appeared in the absorbing grains enriched area, as thermal expansion induced stress exceeds the strength of the material, cracks initiate in the mineral grain boundaries [11-13]. Meanwhile, the anisotropy of the rock affects the distribution of temperature and stress in the ores [14-16].

For the hard rocks' breakage, the reaction of different kinds of rocks under microwave irradiation has been studied. Rocks (eg. granite, basalt, norite, gabbro et.al) would generate heat and form uneven temperature distribution internally under microwave irradiation [17-19]. High temperatures would cause microscopic or macroscopic cracks even melting in rocks to reduce mechanical strength of rocks, such as point load and uniaxial compression strength [20-22]. The power level, irradiation time, the water content and the parameter of rock all had an influence on breakage effects $[18,19,23]$. In summary, some typical magmatic rocks have proved to can be break down under microwave irradiation.

Though great progress has been achieved by previous research, there are a few reports on the damage of diorite which is also the typical magmatic rock under microwave. Magmatic rocks are hard and widely distributed in the earth crust, whose effective excavation is a frequently encountered problems in engineering application. Only several studies had demonstrated the effect of high temperature on the mechanical properties of diorite [24]. Furthermore, it needs to be noticed that conventional heating which rely on heat sources transferring is different from the microwave volumetric heating [25]. For a better and extended understanding on the reaction of magmatic rocks under microwave, it is necessary to study the failure of diorite under microwave irradiation.

In this study, the diorite block was processed into cube and whose reaction process at a series of high temperatures in a microwave muffle furnace was studied. After the experiments, scanning electron microscope (SEM), X-ray diffraction (XRD) and compressive strength test are to be exploited to study the irradiated samples in detail and to evaluate the overall damage trend of the samples.

\section{EXPERIMENTAL}

\section{Experimental design Subparagraph}

single mode commercial microwave system (HAMiLab-M1500) is adopted to irradiate the specimen. The system is capable of outputting continual and adjustable power $(0.2-1.45 \mathrm{~kW})$ microwave with the frequency of 2.45 1 GHz. An infrared thermometer on the inner furnace wall can measure the sample surface temperature which is actually lower than the internal one. Alumina block is used around the sample for insulation. 
Before microwave irradiation, all the specimens are dried in oven at $105^{\circ} \mathrm{C}$ for $24 \mathrm{~h}$. Based on the size of the experimental instrument, diorite blocks are processed to cube specimens with a length of $2.5 \mathrm{~cm}$ by water-cooled diamond blade. The damage of the cube is pre-evaluated and each set contains two samples which are selected out for testing without visible cracks on all six sides. Specimens are heated in microwave system, which is set to increase temperature at an average rate of $15-20^{\circ} \mathrm{C} / \mathrm{min}$. After temperature reached the assigned value $\left(300^{\circ} \mathrm{C}, 400^{\circ} \mathrm{C}, 500{ }^{\circ} \mathrm{C}, 600{ }^{\circ} \mathrm{C}, 700^{\circ} \mathrm{C}, 800^{\circ} \mathrm{C}\right.$, respectively), it will be kept for 15 minutes and then cooled down to the room temperature $\left(25^{\circ} \mathrm{C}\right)$ naturally.

\section{Characterization}

The chemical composition of diorite is measured by X-ray fluorescence (XRF, PANalytical B.V. Axios). The petrographic are obtained by polarizing microscope (Laborlux 12 pol, Leitz). The microstructure was measured by scanning electron microscope (SEM, KYKY-EM8000F). In order to study the thermal properties of the diorite, simultaneous thermogravimetric and differential scanning (TG-DTG) measurements are carried out on thermal analysis equipment (SDT $\mathrm{Q}$ 600) from room temperature $\left(25^{\circ} \mathrm{C}\right)$ to $800{ }^{\circ} \mathrm{C}$ in air atmosphere with a heating rate of $10^{\circ} \mathrm{C} / \mathrm{min}$. Mineral composition change of the samples before and after irradiation is characterized by an X-ray diffractometer (X'Per PRO, Netherlands) with $\mathrm{Cu} \mathrm{K} \alpha$ radiation $(\lambda=1.5406 \AA)$, and the data range is $3 \sim 80^{\circ}$ at a scanning rate of $15^{\circ} / \mathrm{min}$. The uniaxial compression is carried out through compression testing machine (TYE-300) with a maximum load rate of $0.3 \mathrm{kN} / \mathrm{s}$.

\section{RESULTS AND DISCUSSION}

\section{Sample properties}

he diorite was taken from northeast Guangxi province of China. In general, the diorite was hard with celadon color, classified as fine-grained biotite quartz diorite. The chemical composition is listed in Table1, and the diorite petrographic pictures and microstructure are shown in Fig.1 and Fig.2 respectively. It could be learned from Fig.1 that the grain sizes range from $200 \mu \mathrm{m}$ to $1.5 \mathrm{~mm}$, including plagioclase $(69 \%)$, K-feldspar (10\%), quartz (8\%), hornblende $(7 \%)$ and biotite $(5 \%)$, five main mineral compositions. It can also be seen that various minerals have varying degrees of alteration, such as biotite and hornblende altered to chlorite. The diorite sample at room temperature has complete smooth surface, and the cementation between minerals is intact nearly without distinct cracks and holes, as shown in Fig.2.

\begin{tabular}{cccccccc}
\hline Oxide & $\mathrm{SiO}_{2}$ & $\mathrm{Al}_{2} \mathrm{O}_{3}$ & $\mathrm{CaO}$ & $\mathrm{Fe}_{2} \mathrm{O}_{3}$ & $\mathrm{~K}_{2} \mathrm{O}$ & $\mathrm{Na}_{2} \mathrm{O}$ & $\mathrm{MgO}$ \\
\hline Content (wt\%) & 63.36 & 16.36 & 5.51 & 5.33 & 3.04 & 2.67 & 2.32 \\
\hline
\end{tabular}

Table 1: Chemical composition of virgin diorite.
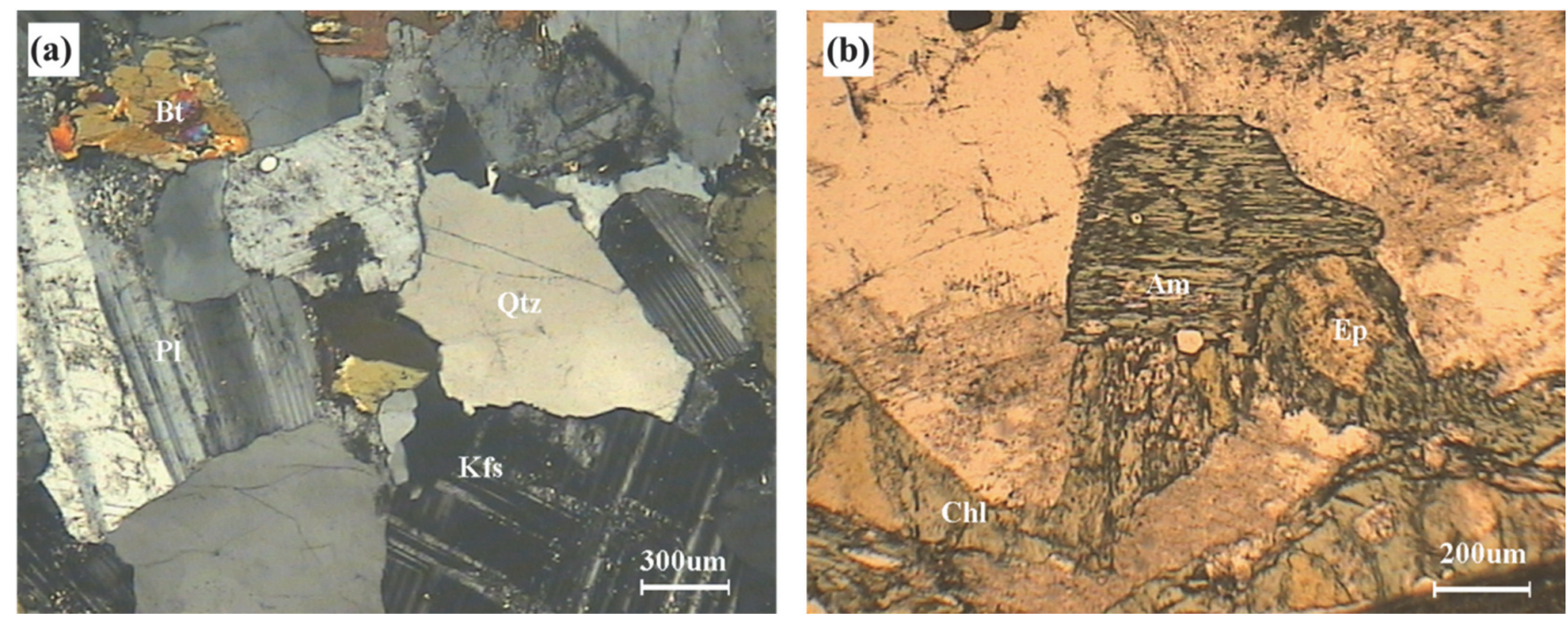

Figure 1: Petrographic images of virgin diorite. (Qtz- quartz; Pl- plagioclase; Bt- biotite; Kfs- K-feldspar; Am- amphibole; Chl- chlorite; Ep- epidote) 


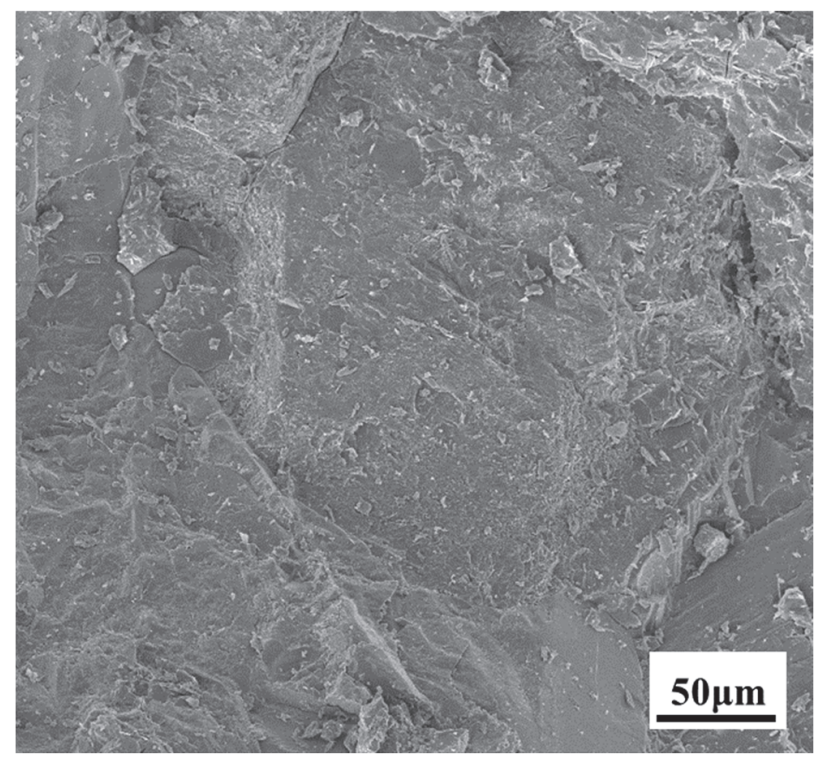

Figure 2: Microstructural image of sample at room temperature.

\section{Thermal properties}

Fig. 3 presents the TG-DSC curves of untreated diorite. The TG curve demonstrates three distinct phases. In the first phase (from 25 to $250^{\circ} \mathrm{C}$ ), the gentle weight loss is normally attributed to the removing of adsorbed water from room temperature to $100{ }^{\circ} \mathrm{C}$ [26] and later some crystal water is released from crystal lattices [27]. Then more crystal water and structural water of minerals escape in phase 2 (from 250 to $530^{\circ} \mathrm{C}$ ) [26]. In the last phase (from 530 to $800{ }^{\circ} \mathrm{C}$ ), the sharp decline in mass around $600{ }^{\circ} \mathrm{C}$ is identified as the process of dehydroxylation of biotite [28]. In the DSC curve, a small endothermic peak can be easily found at $573^{\circ} \mathrm{C}$, which is attributed to quartz $\alpha-\beta$ transition $[29,30]$. The stress increases due to the enlargement of volume in quartz mineral grains during the phase transition, on the other hand, its surface energy becomes very low in this course. Consequently, cracking occurs easily in the rock [31].

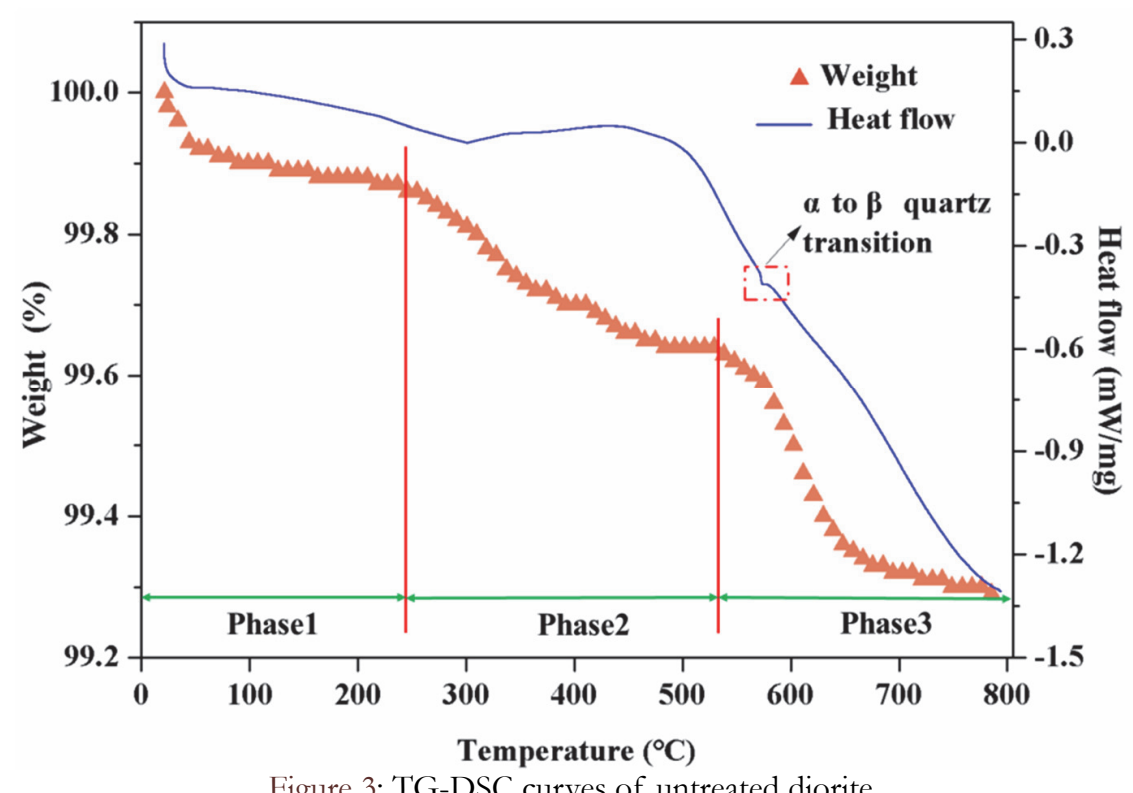

\section{Irradiating outcomes}

A series of diorite samples after irradiation with different temperatures are presented in Fig.4. It can be seen that irradiated samples exhibit obvious changes in the morphology. After $300{ }^{\circ} \mathrm{C}$ and $400{ }^{\circ} \mathrm{C}$ treatment, the diorite appearance shows unchanged comparison to the original one, as shown in Fig.4a and b. As indicated in Fig. 4c, the light-colored minerals on 
the surface have turned to white, while dark minerals such as biotite turned to brown and the biotite layer demonstrate golden in the fractured area. This is because of the water losing in Fe-rich minerals [29]. Besides, it can be found that cracks initially appear around the biotite particles which are also split by cracks.

At $600{ }^{\circ} \mathrm{C}$, the sample exhibits a pattern of radial crack initiated from the biotite region. It is inferred that the biotite is initially heated to high temperature under microwave irradiation, which is due to the microwave sensitive materials in the diorite. The volume of biotite can expand nearly 2.5 times at high temperature and stress concentration on the biotite crystal boundary would affect the surrounding minerals [4,30]. When the temperature beyond $600{ }^{\circ} \mathrm{C}$, the sample cracks and develops into whole disintegration. With continual increasing of the temperature, the number of cracks further multiplies. The sample begins to disintegrate, as a result, small particles and powder fall off. The rock appears loose, whose interior and surface are covered with cracks of various sizes, as shown Fig3.e and $\mathrm{f}$. This is partly because of different volume expansion rate, such as quartz (37.0), biotite (36.6), plagioclase (10.4 14.0), and hornblende (23.8) [31], and the effects of mismatch between different minerals expansion intensified, which is considered to be a more relevant factor than volumetric expansion [30]. On the other hand, the phase transition of quartz plays a major role in the damage effects under high temperature, which causes the thermal expansion of the granite to exhibit significant plasticity [23].
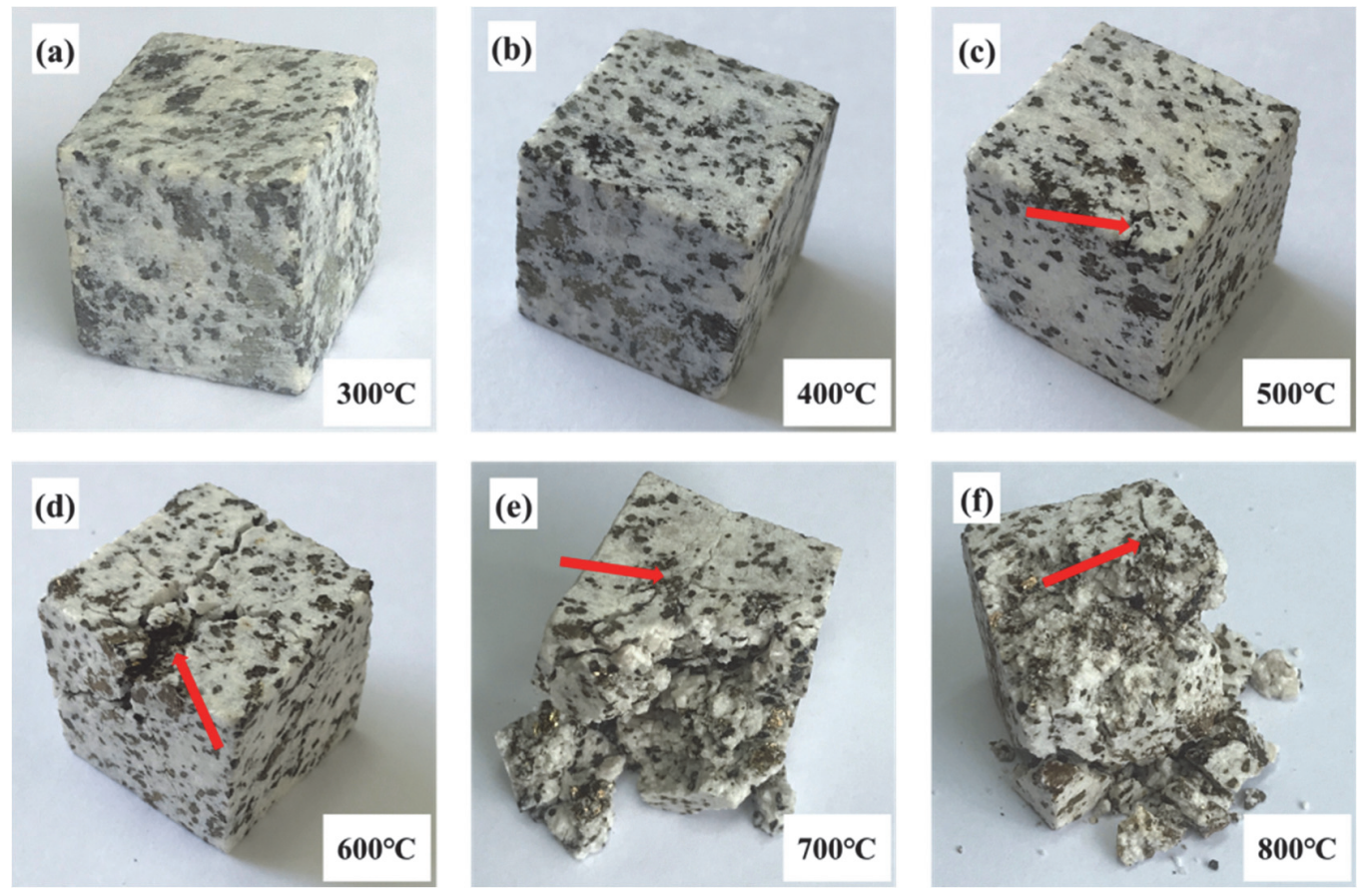

Figure 4: Morphology of diorite exposed to different temperatures after irradiation. (Cracks were indicated)

\section{Microstructure analysis}

The SEM images of the diorite surface at different temperatures are presented in Fig.5. As shown in Fig. 5a and b, the crystal structure and surface have not been destroyed. However, some pores and micro cracks can be observed. Beyond 500 ${ }^{\circ} \mathrm{C}$, macro cracks appear and increase both in size and number with temperature increasing, then gradually form crack networks surrounding crystal grains. It can be seen in Fig.5 (d) that cracks not only occur within the feldspar and biotite, but also at the interface between the two minerals. Besides, some layered mineral fragments fall off the surface of biotite. When the temperature increases to $700{ }^{\circ} \mathrm{C}$, the cracks have further developed, whose length and surface density increase significantly, and specimens' surface is broken into different fragments.

\section{Minerals composition analysis}

The XRD patterns of diorite samples after high temperature exposure are summarized in Fig.6. The results of mineral analysis from XRD are consistent with the findings from petrographic pictures. It can be seen that there is no distinct change in biotite and quartz. The diffraction peak intensity of hornblende gradually decreases with increasing temperature, which indicates that hornblende content gradually decreases with increasing temperature. Several diffraction peaks of chlorite disappear after $500{ }^{\circ} \mathrm{C}$ treatment, it might suggest that chlorite is decomposed or turn into amorphous when the 
temperature beyond $500{ }^{\circ} \mathrm{C}$. According to the previous mineralogical analysis, the chlorite is produced by the alteration of hornblende and biotite, which proves the instability of the chlorite produced by the alteration at high temperatures.
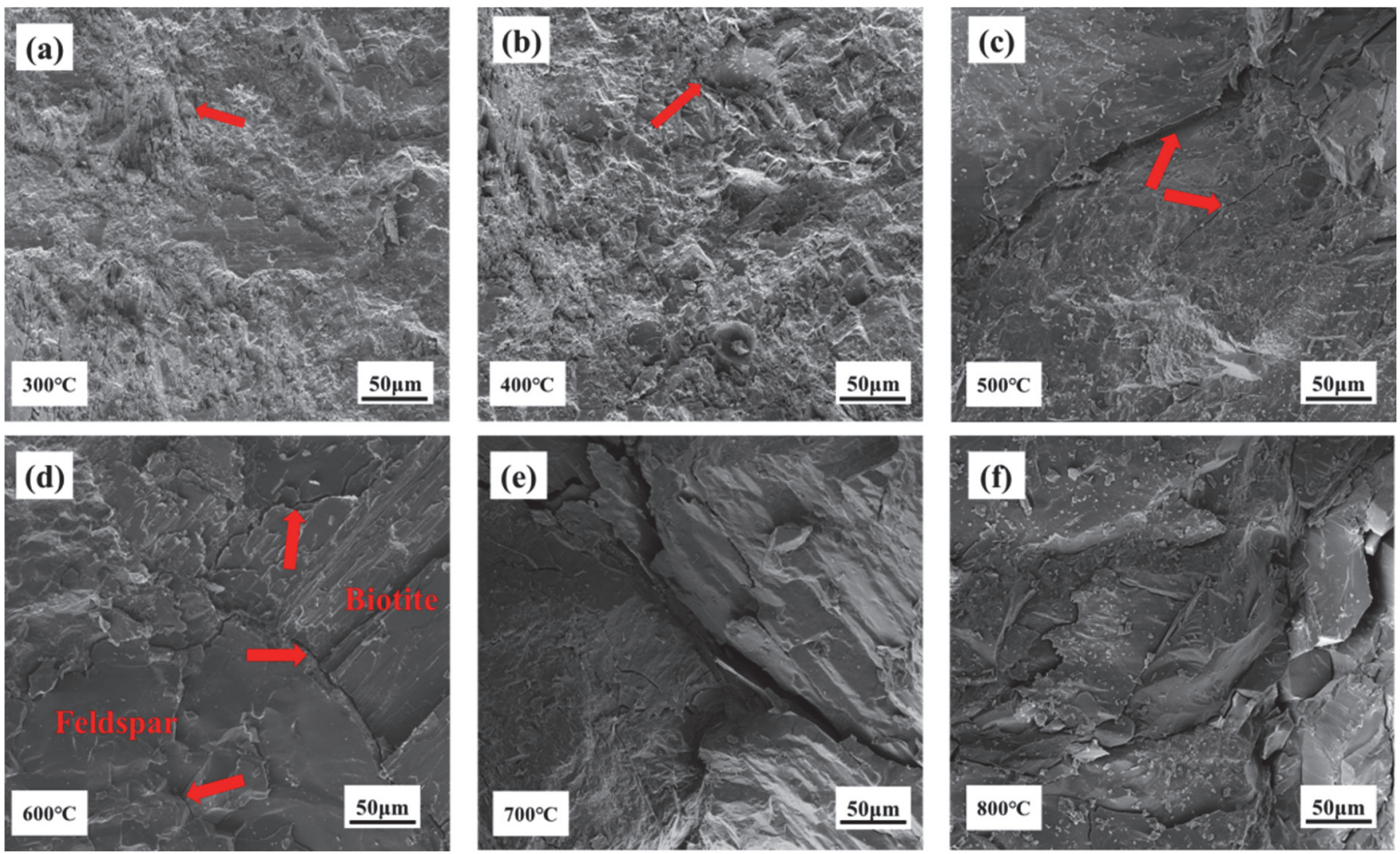

Figure 5: Microscopic images of diorite after different heating treatment. (Cracks were indicated)
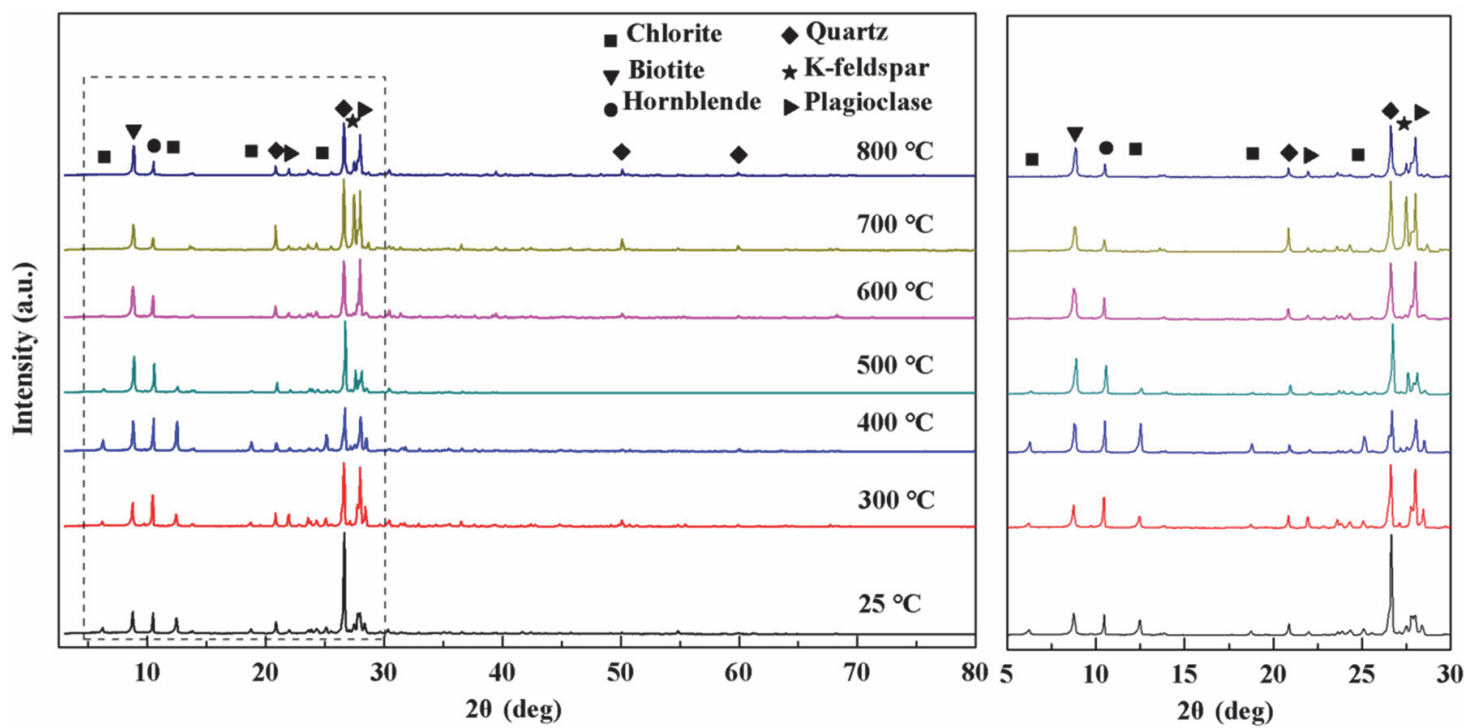

Figure 6: XRD patterns for diorite samples before and after high temperatures treatment.

\section{Compressive strength}

The mean compressive strength test was carried out to quantitatively evaluate of the overall damage trend of specimens with temperature. Fig.7 shows peak compressive strength of samples as a function of exposure temperature. It is clear that with increasing temperature, compressive strength decreases slowly from room temperature to $500{ }^{\circ} \mathrm{C}$ initially while it drops sharply between $500{ }^{\circ} \mathrm{C}$ and $600^{\circ} \mathrm{C}$. The value decrease by approximately $60 \%$ from $133.2 \mathrm{MPa}$ at room temperature to $57.8 \mathrm{MPa}$ at $600{ }^{\circ} \mathrm{C}$. It is reasonable to deduce that the compressive strength approaches zero at $700^{\circ} \mathrm{C}$. 
According to the above analysis, it could be inferred the mechanical properties damage process. Due to the damage of mineral for water losing [26,27] under $600{ }^{\circ} \mathrm{C}$, the strength drops slowly for the damage is not serious. Then the quartz phase transition at $573{ }^{\circ} \mathrm{C}$ causes structural changes and higher thermal stress [15], meanwhile the thermal expansion mismatch would be more severe with increasing temperature. However, quartz content of the diorite in this research is only $8 \%$. Accordingly, the thermal expansion mismatch may be a more important factor to the decline of compressive strength at elevated temperatures.

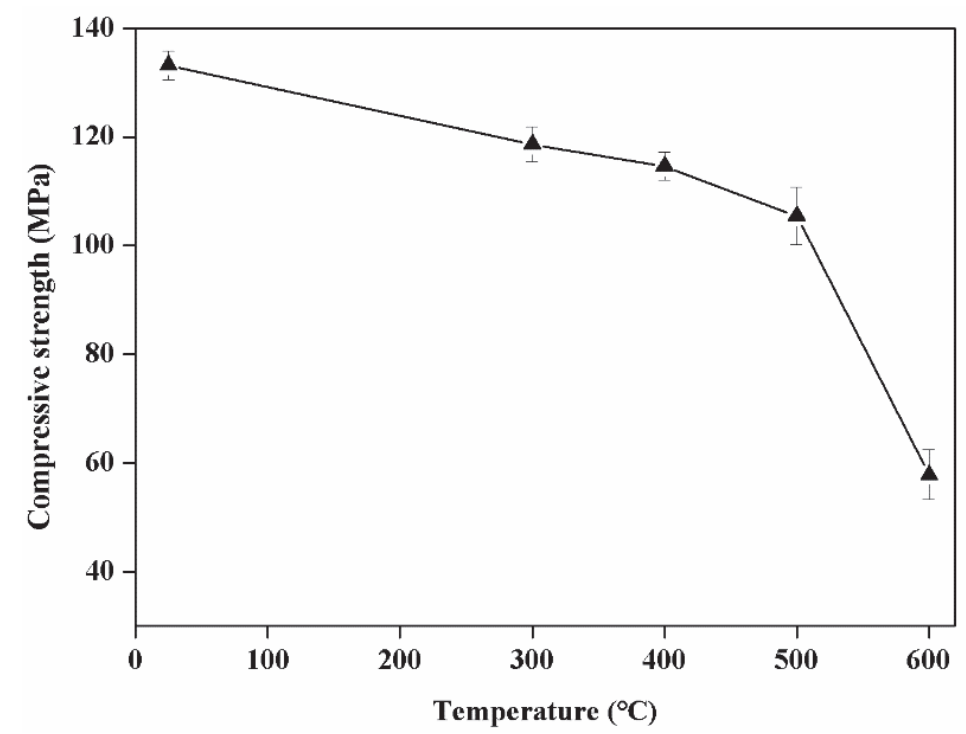

Figure 7: Peak compressive strength of diorite samples at different temperatures.

\section{CONCLUSION}

7 his paper presents the influence of high temperature on the diorite structure induced by microwave irradiation at temperature range of $300{ }^{\circ} \mathrm{C}$ to $800^{\circ} \mathrm{C}$ for 15 minutes. The experimental results demonstrate that high temperatures could destroy the structure of the rock and reduce its mechanical properties. Thermal micro cracks originate in biotite enrichment area and develop into macro network cracks. Minerals composition has not changed while the chlorite decomposes or transform into amorphous after more than $500^{\circ} \mathrm{C}$. Compressive strength significantly reduces with the appearance of initial cracks at $500{ }^{\circ} \mathrm{C}$, then reduces by $60 \%$ at $600{ }^{\circ} \mathrm{C}$ treatment and the structure completely disintegrates at $700{ }^{\circ} \mathrm{C}$ and $800{ }^{\circ} \mathrm{C}$. The study demonstrates it feasible that the application of microwaves could be used for diorite destruction.

\section{ACKNOWLEDGEMENT}

7 his work was supported by National Natural Science Foundation of China (No. 21677118, No. 41574100, No. 21471088).

\section{REFERENCES}

[1] Kingman, S. W., Jackson, K., Cumbane, A., et al. (2004). Recent developments in microwave-assisted comminution, Int. J. Miner. Process., 74(1), pp. 71-83. DOI: 10.1016/j.minpro.2003.09.006.

[2] Lu, G.M., Li, Y.H., Hassani, F., and Zhang X.W. (2016). Review of theoretical and experimental studies on mechanical rock fragmentation using microwave-assisted approach, Chin. J. Geotech. Eng., 38(8), pp. 1497-1506.

DOI:10.11779/CJGE201608018. 
[3] Monti, T., Tselev, A., Udoudo, O., et al. (2016). High-resolution dielectric characterization of minerals: A step towards understanding the basic interactions between microwaves and rocks, Int. J. Miner. Process., 151, pp. 8-21.

DOI: 10.1016/j.minpro.2016.04.003.

[4] Lu, G.M., Li, Y.H., Hassani F, et al. (2017). The influence of microwave irradiation on thermal properties of main rockforming minerals, Appl. Therm. Eng., 112, pp. 1523-1532. DOI: 10.1016/j.applthermaleng.2016.11.015.

[5] Clark, D.E. and Sutton, W.H. (1996). Microwave processing of materials, Annu. Rev. Mater. Sci., 26(1), pp. $299-331$. DOI: 10.1146/annurev.ms.26.080196.001503.

[6] Chen, T.T., Dutrizac, J.E., Haque, K.E., et al. (1984). The relative transparency of minerals to microwave radiation, Can. Metall. Quart., 23(3), pp. 349-351. DOI: 10.1179/cmq.1984.23.3.349.

[7] Kingman, S.W., Vorster, W. and Rowson, N.A. (2000). The influence of mineralogy on microwave assisted grinding, Miner. Eng., 13(3), pp. 313-327. DOI: 10.1016/S0892-6875(00)00010-8.

[8] Scott, G., Bradshaw, S.M. and Eksteen, J.J. (2008). The effect of microwave pretreatment on the liberation of a copper carbonatite ore after milling, Int. J. Miner. Process., 85(4), pp. 121-128. DOI: 10.1016/j.minpro.2007.08.005.

[9] Zhao, W., Chen, J., Chang, X., et al. (2014). Effect of microwave irradiation on selective heating behavior and magnetic separation characteristics of Panzhihua ilmenite, Appl. Surf. Sci., 300(3), pp. 171-177. DOI: $10.1016 /$ j.apsusc.2014.02.038.

[10] John, R.S., Batchelor, A.R., Ivanov, D., et al. (2015). Understanding microwave induced sorting of porphyry copper ores, Miner. Eng., 84, pp. 77-87. DOI: 10.1016/j.mineng.2015.10.006.

[11] Whittles, D.N., Kingman, S.W. and Reddish, D.J. (2003). Application of numerical modelling for prediction of the influence of power density on microwave-assisted breakage, Int. J. Miner. Process., 68(1), pp. 71-91. DOI: $10.1016 / \mathrm{S} 0301-7516(02) 00049-2$.

[12] Jones, D.A., Kingman, S.W., Whittles, D.N., et al. (2005). Understanding microwave assisted breakage, Miner. Eng., 18(7), pp. 659-669. DOI: 10.1016/j.mineng.2004.10.011.

[13] Wang, G., Radziszewski, P. and Ouellet, J. (2008). Particle modeling simulation of thermal effects on ore breakage, Comp. Mater. Sci., 43(4), pp. 892-901. DOI: 10.1016/j.commatsci.2008.02.005.

[14] Meisels, R., Toifl, M., Hartlieb, P., et al. (2015). Microwave propagation and absorption and its thermo-mechanical consequences in heterogeneous rocks, Int. J. Miner. Process., 135(3), pp. 40-51. DOI: 10.1016/j.minpro.2015.01.003.

[15] Toifl, M., Meisels, R., Hartlieb, P., et al. (2016). 3D numerical study on microwave induced stresses in inhomogeneous hard rocks, Miner. Eng., 90, pp. 29-42. DOI: 10.1016/j.mineng.2016.01.001.

[16] Toifl, M., Hartlieb, P., Meisels, R., et al. (2017). Numerical study of the influence of irradiation parameters on the microwave-induced stresses in granite, Miner. Eng., 103, pp. 78-92. DOI: 10.1016/j.mineng.2016.09.011.

[17] Hartlieb, P., Leindl, M., Kuchar, F., et al. (2012). Damage of basalt induced by microwave irradiation, Miner. Eng., 31(3), pp. 82-89. DOI: 10.1016/j.mineng.2012.01.011.

[18] Hassani, F., Nekoovaght, P.M. and Gharib, N. (2016). The influence of microwave irradiation on rocks for microwaveassisted underground excavation, J. Rock. Mech. Geotech. Eng., 8(1), pp. 1-15. DOI: 10.1016/j.jrmge.2015.10.004.

[19] Zheng, Y.L., Zhang, Q.B. and Zhao, J. (2017). Effect of microwave treatment on thermal and ultrasonic properties of gabbro, Appl. Therm. Eng., 127, pp. 359-369. DOI: 10.1016/j.applthermaleng.2017.08.060.

[20] Satish, H., Ouellet, J., Raghavan, V., et al. (2005). Investigating microwave assisted rock breakage for possible space mining applications, Min. Techno., 115(1), pp. 34-40. DOI: 10.1179/174328606X101902.

[21] Peinsitt, T., Kuchar, F., Hartlieb, P., et al. (2010). Microwave heating of dry and water saturated basalt, granite and sandstone, Int. J. Min. Miner. Eng., 2(1), pp. 18-29. DOI: 10.1504/IJMME.2010.03181.

[22] Hartlieb, P., Grafe, B., Shepel, T., et al. (2017). Experimental study on artificially induced crack patterns and their consequences on mechanical excavation processes, Int. J. Rock. Mech. Min., 100, pp. 160-169.

DOI: $10.1016 / j . i j r m m s .2017 .10 .024$.

[23] Hartlieb, P., Toifl, M., Kuchar, F., et al. (2016). Thermo-physical properties of selected hard rocks and their relation to microwave-assisted comminution, Miner. Eng., 91, pp. 34-41. DOI: 10.1016/j.mineng.2015.11.008.

[24] Tian, H., Mei, G., Jiang, G.S., et al. (2017). High-Temperature Influence on Mechanical Properties of Diorite, Rock. Mech. Rock. Eng., 50(6), pp. 1661-1666. DOI: 10.1007/s00603-017-1185-3.

[25] Farag, S., Sobhy, A., Akyel, C., et al. (2012). Temperature profile prediction within selected materials heated by microwaves at 2.45GHz, Appl. Therm. Eng., 36(1), pp. 360-369. DOI: 10.1016/j.applthermaleng.2011.10.049.

[26] Sun, Q., Zhang, W., Xue, L., et al. (2015). Thermal damage pattern and thresholds of granite, Environ. Earth. Sci., 74(3), pp. 2341-2349. DOI: $10.1007 / \mathrm{s} 12665-015-4234-9$.

[27] Zuo, J.P., Wang, J.T., Sun, Y.J., et al. (2017). Effects of thermal treatment on fracture characteristics of granite from Beishan, a possible high-level radioactive waste disposal site in China, Eng. Fract. Mech., 182, pp. 425-437. 
DOI: 10.1016/j.engfracmech.2017.04.043.

[28] Labus, M. and Lempart, M. (2018). Studies of polish Paleozoic shale rocks using FTIR and TG/DSC methods, J. Petrol. Sci. Eng., 161, pp. 311-318. DOI: 10.1016/j.petrol.2017.11.057.

[29] Plevova, E., Vaculikova, L., Kozusnikova, A., et al. (2016). Thermal expansion behaviour of granites. J. Therm. Anal. Calori., 123(2), pp. 1555-1561. DOI: 10.1007/s10973-015-4996-z.

[30] Sun, Q., Zhang, W., Su, T., et al. (2016). Variation of Wave Velocity and Porosity of Sandstone after High Temperature Heating. Acta. Geophys., 64(3), pp. 633-648. DOI: 10.1515/acgeo-2016-0021.

[31] Glover, P.W.J., Baud, P., Darot, M., et al. (1995). $\alpha / \beta$ phase transition in quartz monitored using acoustic emissions. Geophys. J. R. Astron. Soc., 120(3), pp. 775-782. DOI: 10.1111/j.1365-246X.1995.tb01852.x.

[32] Becattini, V., Motmans, T., Zappone, A., et al. (2017). Experimental investigation of the thermal and mechanical stability of rocks for high-temperature thermal-energy storage, Appl. Energ., 203, pp. 373-389. DOI: $10.1016 /$ j.apenergy.2017.06.025.

[33] Vázquez, P., Shushakova, V. and Gómez-Heras, M. (2015). Influence of mineralogy on granite decay induced by temperature increase: Experimental observations and stress simulation, Eng. Geol., 189, pp. 58-67.

DOI: $10.1016 /$ j.enggeo.2015.01.026.

[34] Siegesmund, S., Sousa, L. and Knell, C. (2018). Thermal expansion of granitoids, Environ. Earth. Sci., 77(2), pp. 41. DOI: $10.1007 / \mathrm{s} 12665-017-7119-2$. 